Research Article

\title{
Investigation of Multiple Hole Grouting for Reducing Water Inrush Risk in Underground Engineering
}

\author{
Changde Yang $\mathbb{D},{ }^{1,2}$ Ling $L i \mathbb{D}^{2},{ }^{2}$ Ying $L i \mathbb{D}^{3},{ }^{3}$ and Yakuan Gao $\mathbb{D}^{3}$ \\ ${ }^{1}$ School of Mines, China University of Mining and Technology, Xuzhou 221008, Jiangsu, China \\ ${ }^{2}$ School of Mining Engineering and Geology, Xinjiang Institute of Engineering, Urumqi 830023, \\ Xinjiang Uygur Autonomous Region, China \\ ${ }^{3}$ School of Civil Engineering, Xuchang University, No. 88 Bayi Road, Xuchang, Henan 461000, China \\ Correspondence should be addressed to Changde Yang; ycdxjgc20@hotmail.com
}

Received 1 November 2021; Accepted 25 November 2021; Published 11 December 2021

Academic Editor: Bingxiang Yuan

Copyright (c) 2021 Changde Yang et al. This is an open access article distributed under the Creative Commons Attribution License, which permits unrestricted use, distribution, and reproduction in any medium, provided the original work is properly cited.

\begin{abstract}
Reinforcement with grout as an environmentally friendly technology has played a key role in underground coal mining. The risk of the water inrush into coal mines can all be reduced by grouting. A model that integrates a geographic information system (GIS), distribution of quantity of grouting injected, and water inflow correlation method is proposed here to evaluate the effects of grouted reinforcement in coal mining. The temporal and spatial characteristics of the volume of grout injected and water yield of aquifers are analyzed by using the GIS, and the rate of filling of cement slurry and its distribution characteristics are determined. The effects of grouting on the aquifers which has been carried out to reduce their permeability are determined by comparing the spatial temporal variations in the volume of the grout injected, water yield, and rate of filling of the cement slurry. The method was applied in a case study in a coalmine in Henan province, China, in which the risk of the water inrush from karst aquifers has been reduced by grouting. There are three limestone aquifers, namely, $\mathrm{L}_{8}, \mathrm{~L}_{10}$, and $\mathrm{L}_{11}$ which underlie an exploitable coal seam. The result indicates that most of the cement slurry is consumed when the water yield is 20 to $30 \mathrm{~m}^{3} / \mathrm{h}$; and that there are minimal changes of the electrical properties of the rock stratum under coal seam when the water yield of $\mathrm{L}_{11}$ is low within the range of $40 \mathrm{~m}$. The resistivity of the aquifers before and after grouting and their spatial characteristics are tested by using the transient electromagnetic method (TEM), and this shows that there are no areas with low resistivity. The electrical properties of the strata at a depth that ranges from $40-80 \mathrm{~m}$ with transverse homogeneity show that Aquifers $\mathrm{L}_{10}$ and $\mathrm{L}_{11}$ have been transformed into aquicludes. The reinforcement effect of aquifers with grout is good.
\end{abstract}

\section{Introduction}

There are three main components in mining engineering: characterizing the rock mass structure, applying engineering geology, and understanding the process of data transformation in engineering geology $[1,2]$. The mechanical properties and integrity of the structure of the rock mass can be improved by using grouting as reinforcement, in which the overall structure of the rock can be preserved, and fractures in the rock mass can be sealed. When grouted, the weathering of rock mass is prevented. In recent years, as much as 25 billion tons of coal reserves in Chinese coal mines have been threatened by flooding, more than $50 \%$ are mainly found in the coalfields in North China that date back to the Permo-Carboniferous period [3]. Cambrian or Ordovician limestone is usually found at the bottom of the Permo-Carboniferous strata in the coalmines [4-6]. With increased depth in mining, the coal mine panels face the risk of water inrush from the mine floor [7-9]. Two methods are used when mining is carried out over karst aquifers under high pressure, which are to facilitate drainage to reduce the water pressure and apply grout [10-12]. However, the cost of draining the coal seam increases with increased depth, and the groundwater will be affected. The application of grout to stop water inrush from the coal seam floor and the reconstruction of aquifers are effective methods for preventing and controlling water inrush into the coal seam from the karst aquifers when mining over confined aquifers [13]. The 
techniques for reducing the permeability of aquifers and aquifer reconstruction have gradually matured and were widely used in projects that controlled water inrush into coal mines in the 1990s in China [14, 15]. However, the most direct way to reduce incidents of water inrush is to apply grout, which will seal the water flow channels of fractures, faults, and karsts to reduce permeability or create an aquiclude [16-18]. The effects of grouting are very important. An analysis method with the use of waveform graphs based on radar sensors was proposed to examine the effects of grouting. The pre- and post-plate tectonic eras were detected by using the direct current method, and the effects of grouting were analyzed by comparing the resistance value [19-21]. The transient electromagnetic method (TEM) can be used to determine the position of water on the floor of the work face and found that the permeability is significantly decreased after grouting the rock on the mine floor [22, 23].

Based on the literature, there are 14 different systems to determine the effects of grouting, in which 5 are analyzed in this study, which are the analytical, inspection, excavation sampling, displacement, and geophysical methods as listed in Table 1 [24].

However, the previous research work has been mainly based on one type of method or only use one method, so that the evaluation results are subjective, which means that the accuracy of the results is greatly reduced. There are also no standardized methods for evaluating the quality of the effects of grouting. In fact, the spatial characteristics of the grouting may not be evident. Therefore, the objective of this paper is to analyze the spatial and temporal effects of the distribution of the quantity of grouting injected in accordance with a spatial analysis approach which utilizes a GIS. Moreover, the TEM is also used to determine the electrical resistivity of the rock stratum under coal seam in the process of grouting.

\section{Method}

2.1. Reinforcement of Coal Seam Floor with Grout. Reinforcement with grout is a method for modifying the hydrogeological properties of the rock mass and has been often used in mining. Under a certain grouting pressure, the grout slurry consolidates or forms gel in the voids or channels in rocks which were originally occupied by water [25-29]. Consequently, water inrush from the rock floor is inhibited, and the strength of the aquifer and the performance of the water barrier layer are improved. The aquifer is transformed into an aquiclude, and the water inflow into the panel will be significantly reduced. Reinforcement of the coal seam floor with grout is carried out first by drilling a borehole, and then the panel with the borehole is connected to the layer in which grouting will be applied. When the aquifer on the coal seam floor has lots of water and the water pressure is high or the bottom of the coal seam floor is not thick, the floor has a broken zone in the water control layer. The transformation of the aquifer into an aquifuge by using grouting as a means of inhibiting water seepage means that the thickness of the water resistance layer will be increased and water inrush coefficient is reduced. Reinforcement with grout is used in this study on the upper and lower roadways in the panel, where geophysical
TABLE 1: Classification of evaluation methods of grouting effect.

\begin{tabular}{lc}
\hline Method & Remarks \\
\hline Analytical & $\begin{array}{c}\text { P-Q-t curve } \\
\text { Distribution of quantity of grouting injected } \\
\text { Water inflow correlation } \\
\text { Rate of filling with grout }\end{array}$ \\
\hline $\begin{array}{l}\text { Inspection of } \\
\text { borehole }\end{array}$ & Observations \\
& Coring \\
\hline Excavation & Permeability coefficient test \\
sampling & Grouting mechanism analysis \\
\hline Displacement & Mechanical test \\
estimation & Water level predictions \\
\hline & Deformation predictions \\
Geophysical & Gravitational prospecting \\
prospecting & Magnetic prospecting \\
& Electrical prospecting \\
& Seismic prospecting \\
& Radioactivity prospecting \\
& Geothermal prospecting \\
\hline
\end{tabular}

exploration or drilling or other activities are carried out. By using engineering design parameters of the reinforcement, the measures for reinforcement with grout are determined for the transformation of the aquifer into an aquiclude which results in its relative impermeability or further improves water resistance (Figure 1).

2.2. Spatial Analysis. Spatial analysis is the implementation of techniques that examine the topography, geometry, or geographic properties of different studied entities, involves tools that manipulate and change spatial information, and then extracts the trends from the data [30, 31]. Spatial analysis is carried out with GIS. The spatial analysis functions of GIS (especially the extraction and transmission of implicit information) mainly differentiate GIS and common information systems [32]. Spatial analysis with the use of GIS allows the location and space of geographic objects to be determined through feature extraction and classification of spatial information and image segmentation and acquires spatial distribution information, spatial forms, and spatial changes [33].

Based on the reasonable integration of the collected parameters in the grouting construction, qualitative and quantitative evaluations of the effects of grouting are carried out through analysis and comparison methods, combined with the use of the spatial analysis function in GIS. A spatial analysis with the use of GIS to evaluate the effects of grouting is a novel method of examining underground structures. Two methods are used to characterize the spatial distribution of the water yield and volume of grout injected in a GIS environment which are examining the properties of the distribution of grout and comparing the water yield. In order to analyze the trend of variations in the water yield and volume of grout used, the water yield of aquifers and volume of grout injected into them were first normalized in the GIS. As well, the effects of grouting are evaluated. 


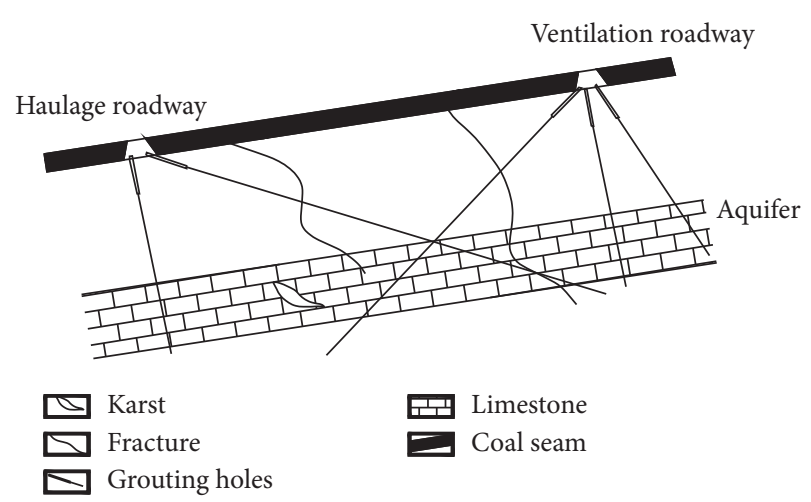

FIGURE 1: Schematic of process of grouting of coal seam floor.

\section{Case Study}

3.1. Geological Background of Coalmine. The Chensilou coalmine is located in the Yongcheng city in Henan province, China $(116.4 \mathrm{E}, 33.9 \mathrm{~N})$. The mean annual temperature is $14.3^{\circ} \mathrm{C}$. The average annual rainfall between 1963 and 2017 is $850.65 \mathrm{~mm}$, with the highest recorded rainfall of $1,518.6 \mathrm{~mm}$ in 1963 and the lowest of $543.7 \mathrm{~mm}$ in 2011. More than 50 percent of the annual precipitation is in the months of July and August. A single horizontal coal seam in the south and north zones was exploited by longwall caving with a longwall retreat system.

Three karst aquifers, namely, $\mathrm{L}_{8}, \mathrm{~L}_{10}$, and $\mathrm{L}_{11}$, underlie Coal Seam II. The average width of the strata between the surface of Aquifers $\mathrm{L}_{8}, \mathrm{~L}_{10}$, and $\mathrm{L}_{11}$ and the bottom of Coal Seam II is $75.8 \mathrm{~m}, 58.6 \mathrm{~m}$, and $43.6 \mathrm{~m}$, respectively. $\mathrm{L}_{10}$ and $\mathrm{L}_{8}$ recharge $\mathrm{L}_{11}$ through the rock crevices. The average thickness of Aquifers $\mathrm{L}_{8}, \mathrm{~L}_{10}$, and $\mathrm{L}_{11}$ is $14.4 \mathrm{~m}, 4.79 \mathrm{~m}$, and $1.40 \mathrm{~m}$, respectively. The maximum water pressure in Aquifers $\mathrm{L}_{8}, \mathrm{~L}_{10}$, and $\mathrm{L}_{11}$ under the floor of Coal Seam II is 6.5 $\mathrm{MPa}$. The water inrush coefficient is calculated by using the following equation:

$$
T_{s}=\frac{P}{M}
$$

where $T$ is the water inrush coefficient, $M$ denotes the aquiclude thickness, and $P$ denotes the water pressure of the confined aquifer. $0.15 \mathrm{MPa} / \mathrm{m}$, which is higher than $0.1 \mathrm{MPa} / \mathrm{m}$. In accordance with the regulations of preventing water hazards for coalmines, reinforcement of these three aquifers with grout is necessary to increase their thickness and transform them into aquicludes. The middle and upper aquifers and the coal seam are hydraulically connected in the middle and upper parts of the Taiyuan formation.

3.2. Grouting and Transient Electromagnetic Method. The grout material is cement slurry with a density of $1.25 \sim 1.35 \mathrm{t} /$ $\mathrm{m}^{3}$. A total of 248 boreholes were drilled into Panel 2517 for grouting. The total water yield and volume of the grout used in Aquifers $\mathrm{L}_{8}, \mathrm{~L}_{10}$, and $\mathrm{L}_{11}$ were determined after drilling. The accumulative water yield of the aquifers is $10,887 \mathrm{~m}^{3} / \mathrm{h}$, and the cumulative volume of grout injected is $19,476.4$ tons.
The maximum water yield of a single borehole in Aquifers $\mathrm{L}_{8}, \mathrm{~L}_{10}$, and $\mathrm{L}_{11}$ is $80 \mathrm{~m}^{3} / \mathrm{h}$, respectively. The volume of grout used in Aquifers $\mathrm{L}_{8}, \mathrm{~L}_{10}$, and $\mathrm{L}_{11}$ is $728 \mathrm{t}, 357 \mathrm{t}$, and $122 \mathrm{t}$, respectively.

A reduplication device was used for the transient electromagnetic process, and a multiturn $2 \mathrm{~m} \times 2 \mathrm{~m}$ rectangular return line was used to make the transmitting and receiving wire frames. The sample window is $1 \sim 34$, and the number of superimpositions is 64 , with the use of a standard time series. A transient electromagnetic survey system (terraTEM) was used. A Pentium III processor, which contains a low energy consumption Pentium series processor, was used with the transient electromagnetic survey system. The field data were processed by using visual software. The display is a 15-inch ultrathin LCD screen with touch function which can greatly improve the efficiency of inputting collected field data with its graphical user interface. The global positioning system (GPS) function was used because it is very convenient for mapping the results. The console was sealed in accordance with the IP66 protocol and can operate in a wet environment. There are 106 measured points in the upper cross sections and 111 measured points in the lower cross sections.

\section{Results}

4.1. Spatial Distribution Characteristics of Water Yield and Volume of Grout. The spatial distribution characteristics of the water yield of Aquifers $\mathrm{L}_{8}, \mathrm{~L}_{10}$, and $\mathrm{L}_{11}$ and volume of grout injected into them are shown in Figures 2 and 3. The total water yield from the 191 water exit points of $\mathrm{L}_{8}$ is $5134 \mathrm{~m}^{3} / \mathrm{h}$, which accounts for $47.2 \%$ of the total water yield. The potential of water from the aquifer is $55.04 \%$, which shows that the aquifer has lots of water which is evenly distributed. The total water yield from all 133 water exit points of $\mathrm{L}_{10}$ is $4966 \mathrm{~m}^{3} / \mathrm{h}$, which accounts for $45.66 \%$ of the total water yield. The potential of water from the aquifer is $85.3 \%$, which shows that the aquifer has lots of water which is evenly distributed. There 23 water exit points in $\mathrm{L}_{11}$, which are mainly distributed on the outside of the panel, and the water yield from the water exit points is $13.6 \%$, which does not correspond to the abundance of water in $\mathrm{L}_{11} \cdot \mathrm{L}_{8}$ and $\mathrm{L}_{10}$ recharge $\mathrm{L}_{11}$ as they contain lots of water and have developed fissures so that the water seeps through the cracks. The water yield and volume of the grout injected for aquifers are listed in Table 2.

The water yield and volume of grout injected into the three aquifers show the characteristics of the fissures filled with water: the proportion of the water yield and volume of grout injected into $\mathrm{L}_{11}$ aquifer is the same, which indicates that the amount of grout used adequately seals the gushing water fissures. There are six types of fissures that fill with water in accordance with the water yield, in which Types I to VI have a water yield of $<10 \mathrm{~m}^{3} / \mathrm{h}, 10-20 \mathrm{~m}^{3} / \mathrm{h}, 20-30$ $\mathrm{m}^{3} / \mathrm{h}, 30-40 \mathrm{~m}^{3} / \mathrm{h}, 40-50 \mathrm{~m}^{3} / \mathrm{h}$, and $>50 \mathrm{~m}^{3} / \mathrm{h}$, respectively (see Table 3).

Table 4 shows that the average volume of grout injected into Type I fissures is $15.9 \mathrm{t}$ but they are only found in $\mathrm{L}_{8}$. In comparison, the volume of grout injected into Type II fissures through a single hole reaches $500 \mathrm{t}$ in $\mathrm{L}_{8}$ (see Table 5). 
TABLE 2: Proportion of water yield and volume of grout injected.

\begin{tabular}{|c|c|c|c|c|c|c|c|c|}
\hline \multirow{2}{*}{ Aquifer } & \multicolumn{2}{|c|}{ Water exit points } & \multicolumn{3}{|c|}{ Water yield $\left(\mathrm{m}^{3} / \mathrm{h}\right)$} & \multicolumn{3}{|c|}{ Volume of grout injected (tons) } \\
\hline & No. & Proportion (\%) & Water yield & Proportion (\%) & Single hole & Volume of grout & Proportion (\%) & Single hole \\
\hline $\mathrm{L}_{8}$ & 191 & 55.04 & 5134 & 47.20 & 26.9 & 8816 & 45.26 & 114.5 \\
\hline $\mathrm{L}_{10}$ & 133 & 38.33 & 4966 & 45.66 & 37.3 & 9229 & 47.38 & 124.7 \\
\hline $\mathrm{L}_{11}$ & 23 & 6.63 & 777 & 7.14 & 33.8 & 1432 & 7.35 & 79.6 \\
\hline Total & 347 & 100.00 & 10877 & 100.00 & 31.3 & 19476.4 & 100.00 & 115.2 \\
\hline
\end{tabular}

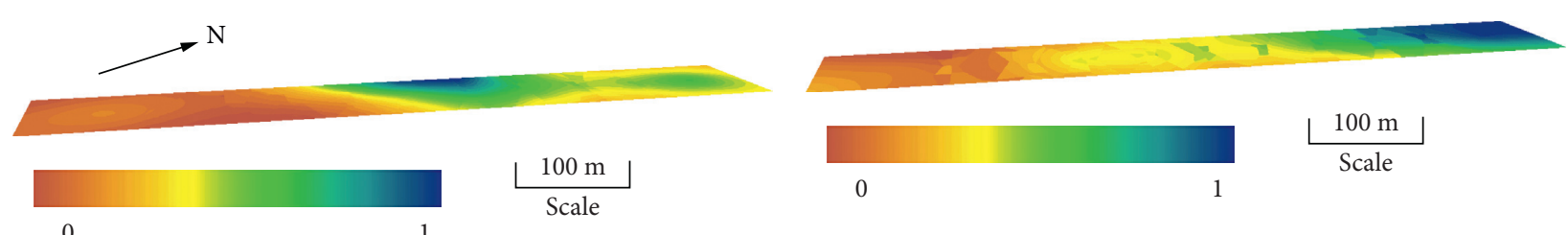

(a)

(b)

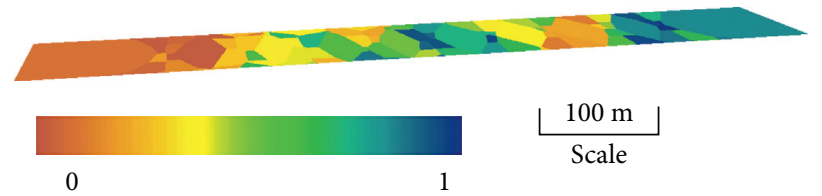

(c)

FIGURE 2: Spatial distribution characteristics of water yield: (a) water yield of $\mathrm{L}_{11}$; (b) water yield of $\mathrm{L}_{10}$; (c) water yield of $\mathrm{L}_{8}$.

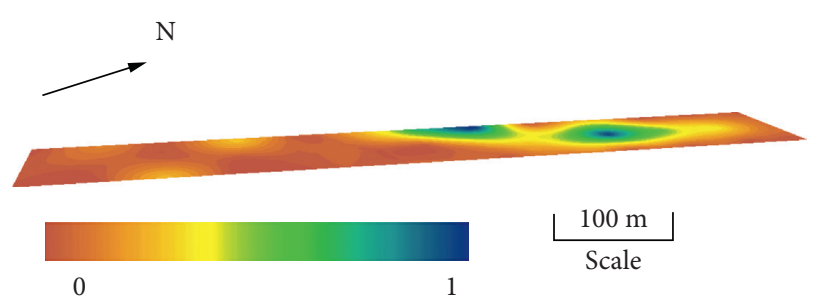

(a)

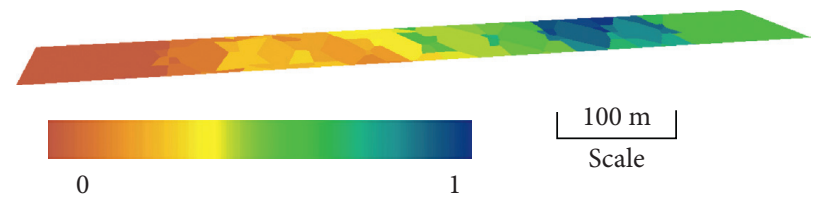

(b)

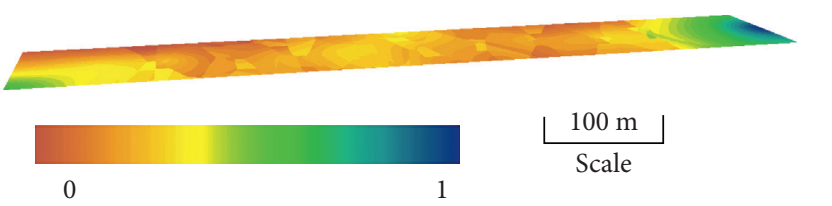

(c)

FIGURE 3: Spatial distribution characteristics of volume grout injected: (a) grouting volume of $\mathrm{L}_{11}$; (b) grouting volume of $\mathrm{L}_{10}$; (c) grouting volume of $\mathrm{L}_{8}$.

TABle 3: Types of fissures filled with water.

\begin{tabular}{lcccccc}
\hline Type of fissure & I & II & III & IV & V & VI \\
\hline Water yield & $<10 \mathrm{~m}^{3} / \mathrm{h}$ & $10-20 \mathrm{~m}^{3} / \mathrm{h}$ & $20-30 \mathrm{~m}^{3} / \mathrm{h}$ & $30-40 \mathrm{~m}^{3} / \mathrm{h}$ & $40-50 \mathrm{~m}^{3} / \mathrm{h}$ & $>50 \mathrm{~m}^{3} / \mathrm{h}$ \\
\hline
\end{tabular}

Table 6 shows that the average volume of grout injected into Type III fissures is $239.6 \mathrm{t}$, and they are mostly found in $\mathrm{L}_{10}$. The volume of grout injected into Type IV fissures through a single hole reaches $191 \mathrm{t}$ in $\mathrm{L}_{10}$ as listed in Table 7.

Table 8 shows that the average volume of grout injected into Type $\mathrm{V}$ fissures is $258 \mathrm{t}$, and they are mostly found in $\mathrm{L}_{8}$. The volume of grout injected into Type VI fissures through a single hole reaches $728 \mathrm{t}$ in $\mathrm{L}_{10}$ as listed in Table 9.

\section{Discussion}

Coal strata are generally found with different layers of rock, with relatively uniform electrical resistivity distributions. The TEM is used to measure the resistivity of coal and other important physical parameters of the properties of the surrounding rock and changes in the resistivity of the surrounding rock and coal in accordance with their 
TABle 4: Type 1 fracture.

\begin{tabular}{lccc}
\hline Aquifer & Water exit points & Total volume of injected grout $(\mathrm{t})$ & Volume of injected grout into one borehole $(\mathrm{t})$ \\
\hline $\mathrm{L}_{8}$ & 10 & 127 & 15.9 \\
$\mathrm{~L}_{10}$ & 0 & 0 & 0.0 \\
$\mathrm{~L}_{11}$ & 0 & 0 & 0 \\
Total & 10 & 127 & 15.9 \\
\hline
\end{tabular}

Table 5: Type II fracture.

\begin{tabular}{lccc}
\hline Aquifer & Water exit points & Total volume of injected grout $(\mathrm{t})$ & Volume of injected grout into one borehole $(\mathrm{t})$ \\
\hline $\mathrm{L}_{8}$ & 38 & 1428 & 42.0 \\
$\mathrm{~L}_{10}$ & 10 & 448 & 44.8 \\
$\mathrm{~L}_{11}$ & 2 & 106 & 53 \\
Total & 50 & 1981.8 & 139.8 \\
\hline
\end{tabular}

TABle 6: Type III fracture.

\begin{tabular}{lccc}
\hline Aquifer & Water exit points & Total volume of injected grout $(\mathrm{t})$ & Volume of injected grout into one borehole $(\mathrm{t})$ \\
\hline $\mathrm{L}_{8}$ & 80 & 2921.9 & 48.7 \\
$\mathrm{~L}_{10}$ & 50 & 3235.0 & 95.1 \\
$\mathrm{~L}_{11}$ & 9 & 766.0 & 95.8 \\
Total & 139 & 6922.9 & 239.6 \\
\hline
\end{tabular}

TABLE 7: Type IV fracture.

\begin{tabular}{lccc}
\hline Aquifer & Water exit points & Total volume of injected grout $(\mathrm{t})$ & Volume of injected grout into one borehole $(\mathrm{t})$ \\
\hline $\mathrm{L}_{8}$ & 32 & 1196.7 & 57.0 \\
$\mathrm{~L}_{10}$ & 23 & 1529.0 & 66.5 \\
$\mathrm{~L}_{11}$ & 5 & 171.0 & 34.2 \\
Total & 60 & 2896.7 & 157.7 \\
\hline
\end{tabular}

TABle 8: Type V fissure.

\begin{tabular}{lccc}
\hline Aquifer & Water exit points & Total volume of injected grout $(\mathrm{t})$ & Volume of injected grout into one borehole $(\mathrm{t})$ \\
\hline $\mathrm{L}_{8}$ & 6 & 435.0 & 72.5 \\
$\mathrm{~L}_{10}$ & 14 & 526.0 & 43.8 \\
$\mathrm{~L}_{11}$ & 2 & 58.0 & 29 \\
Total & 22 & 1019 & 145.3 \\
\hline
\end{tabular}

Table 9: Type VI fissure.

\begin{tabular}{lccc}
\hline Aquifer & Water exit points & Total volume of injected grout $(\mathrm{t})$ & Volume of injected grout into one borehole $(\mathrm{t})$ \\
\hline $\mathrm{L}_{8}$ & 26 & 2708.0 & 117.7 \\
$\mathrm{~L}_{10}$ & 35 & 3490.0 & 105.8 \\
$\mathrm{~L}_{11}$ & 5 & 331.0 & 66.2 \\
Total & 66 & 6529 & 289.7 \\
\hline
\end{tabular}

composition, structure, saturation, and other factors, in which substantial changes are found. In fact, the conductivity of coal bearing strata directly affects its resistivity. When a column collapses or fault zone is filled with water, then the conductivity of the water will show low local resistance in terms of its apparent resistivity [34]. When the volume of water in a developed structure is low or there is no water, the conductivity is poor and the local resistivity is high. The differences in the conductivity of rock are based on their geophysical characteristics; however, the variations in the relationship between the vertical and horizontal resistivities in mines can be examined by using TEM.
The TEM was developed in the mid-1980s and modified since then [35]. More recently, a new electromagnetic method was devised by David Wright and his colleagues, Anton Ziolkowski, and Bruce Hobbs, at the University of Edinburgh in 2001, called the multitransient electromagnetic method (MTEM) [36]. The MTEM involves the use of two electrodes in which a current is introduced into the ground between them. In mining, the MTEM examines the changes in the magnetic field by using an ungrounded current loop placed between the underground roadway and the surrounding space of the roadway. When excitation takes place, the induced eddy current created by the conductivity of the 


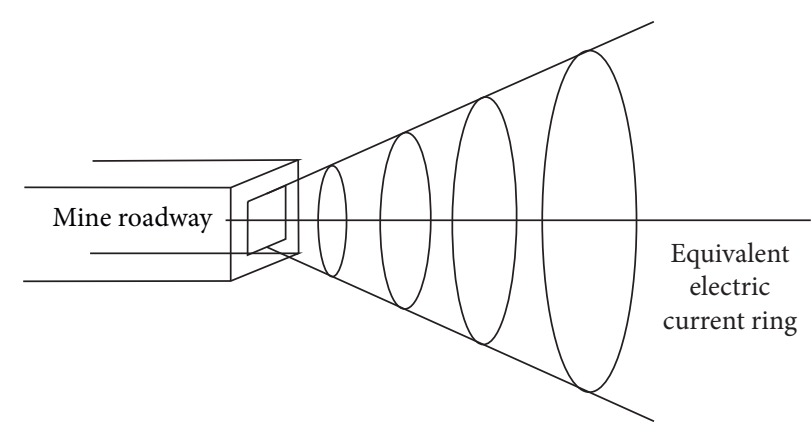

Figure 4: Schematic of transient electromagnetic process in detection of electromagnetic fields.

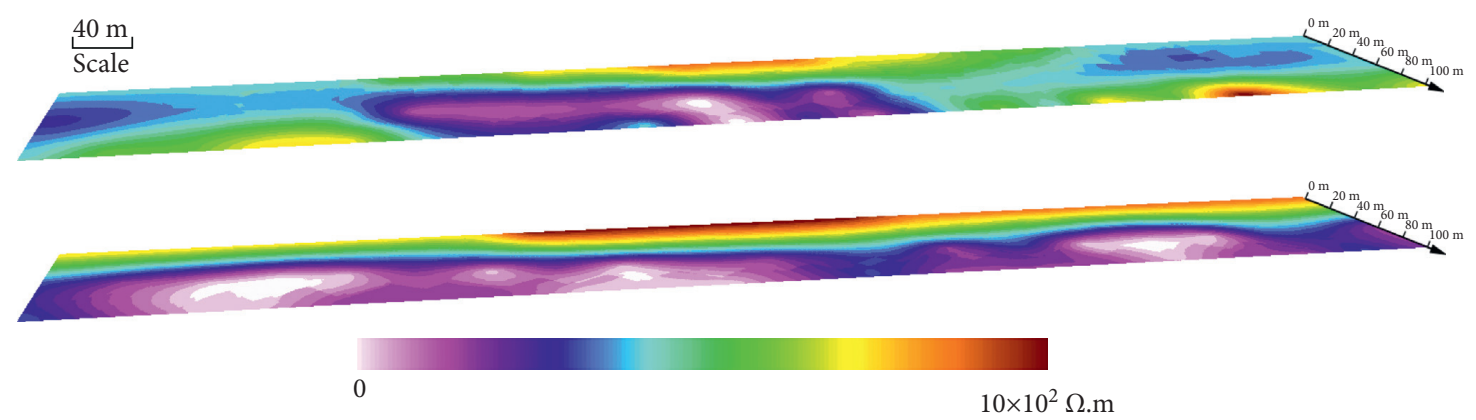

(a)

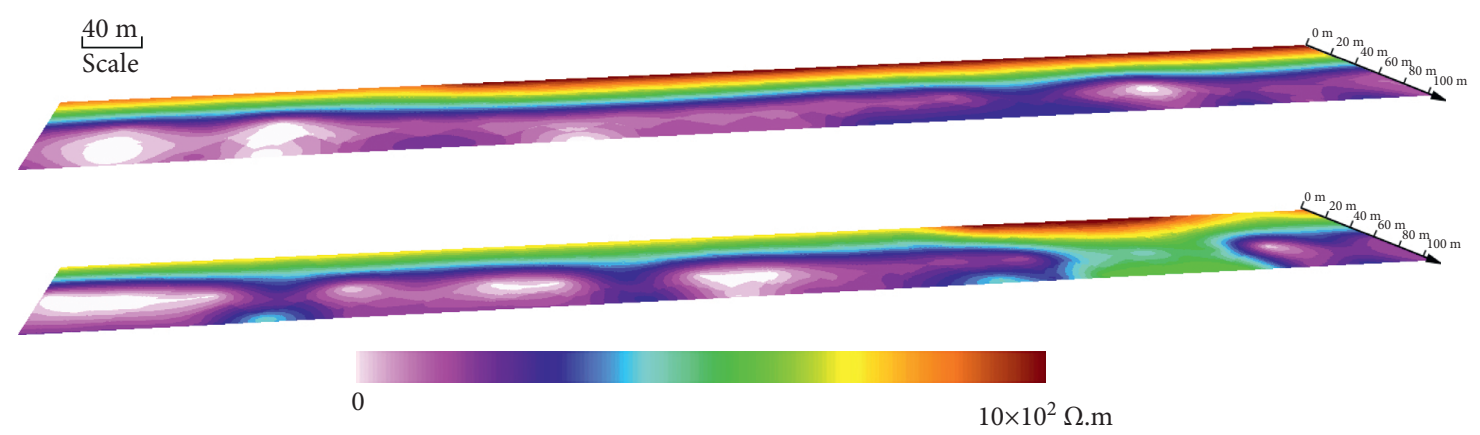

(b)

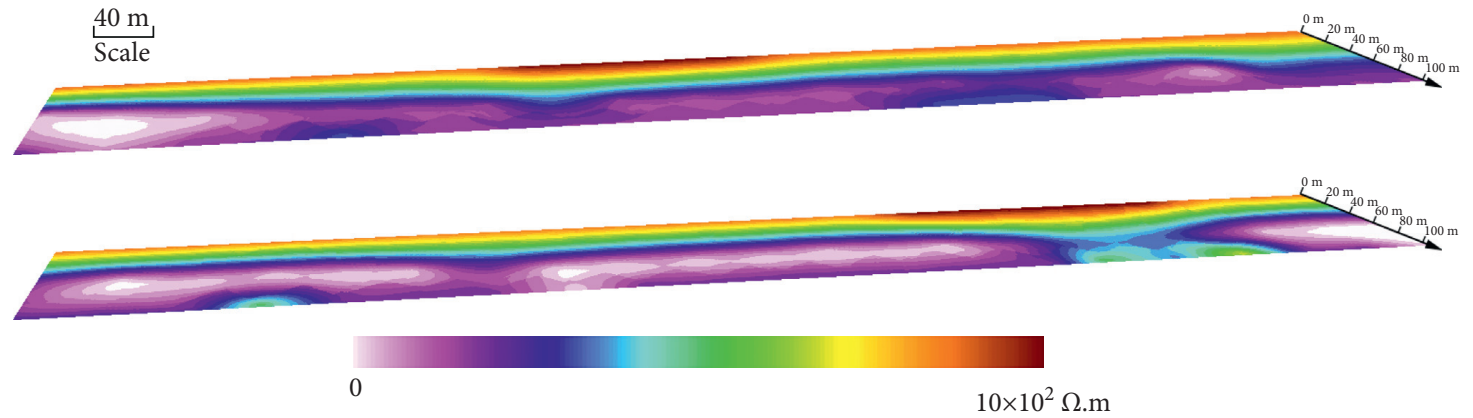

(c)

Figure 5: Continued. 


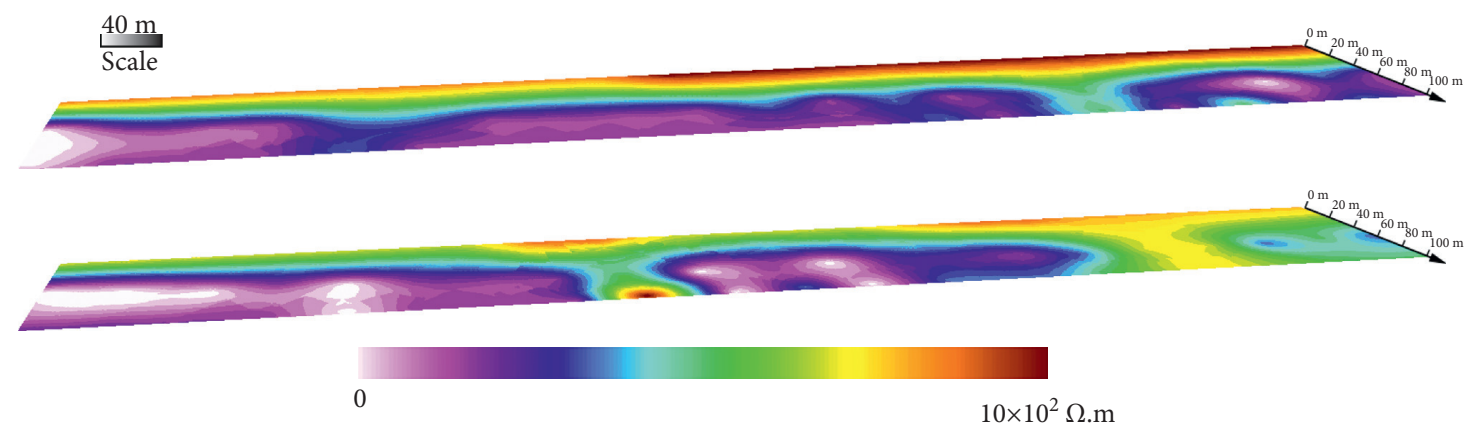

(d)

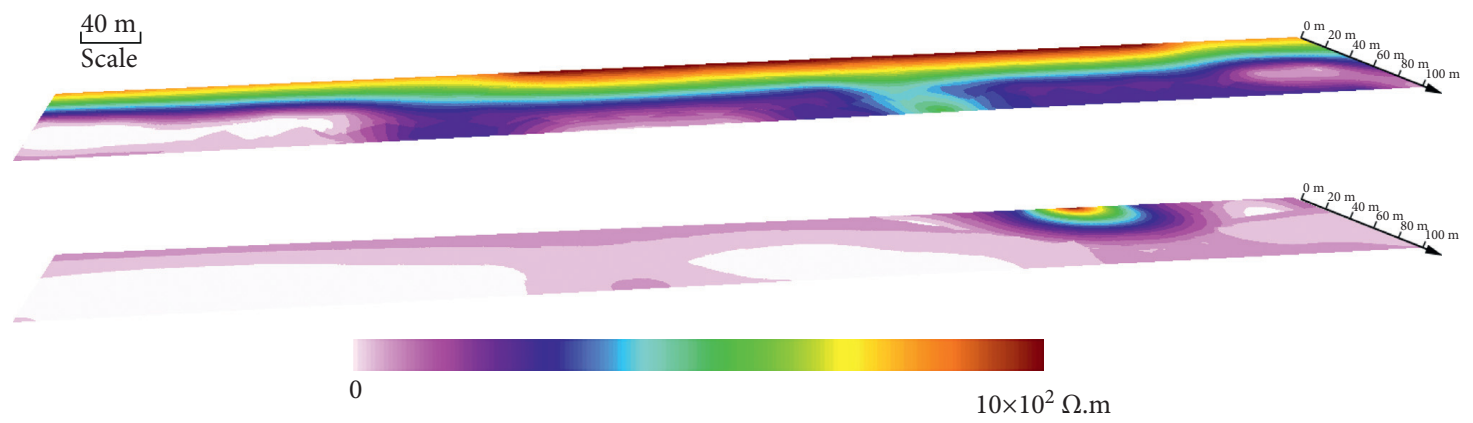

(e)

FIGURE 5: Apparent resistivity of aquifers before grouting.
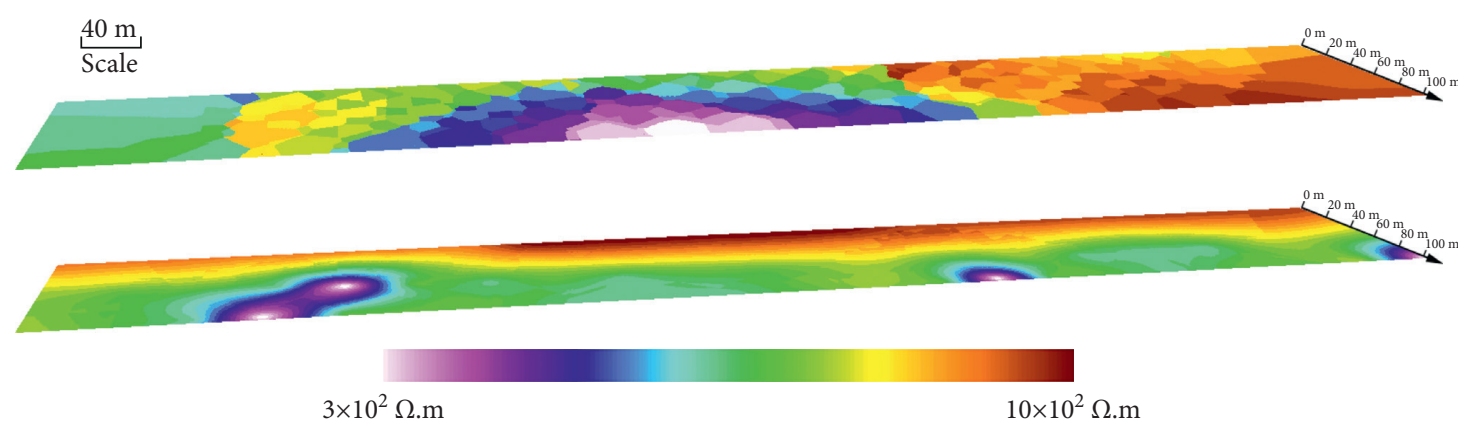

(a)

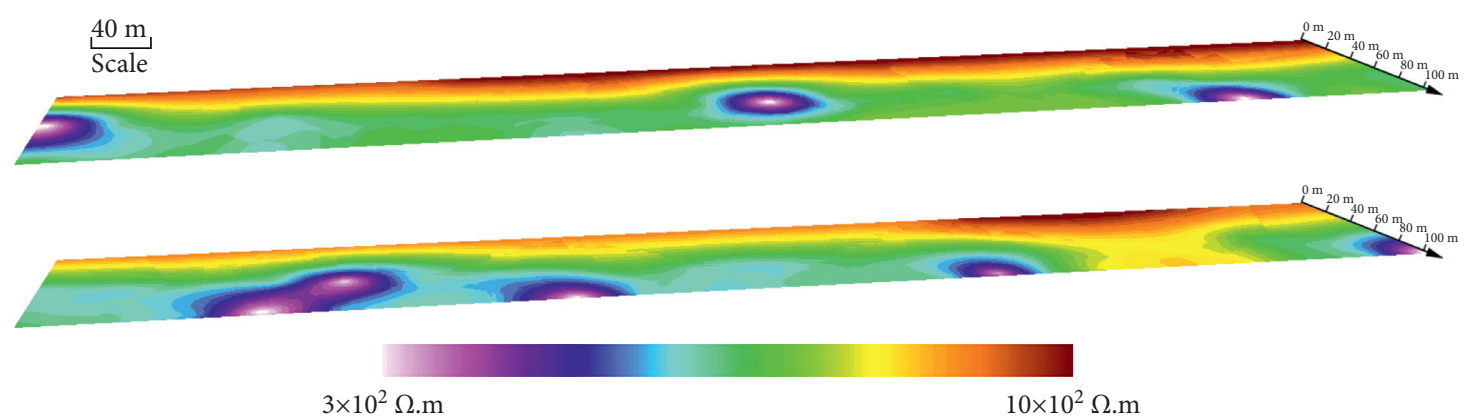

(b)

Figure 6: Continued. 


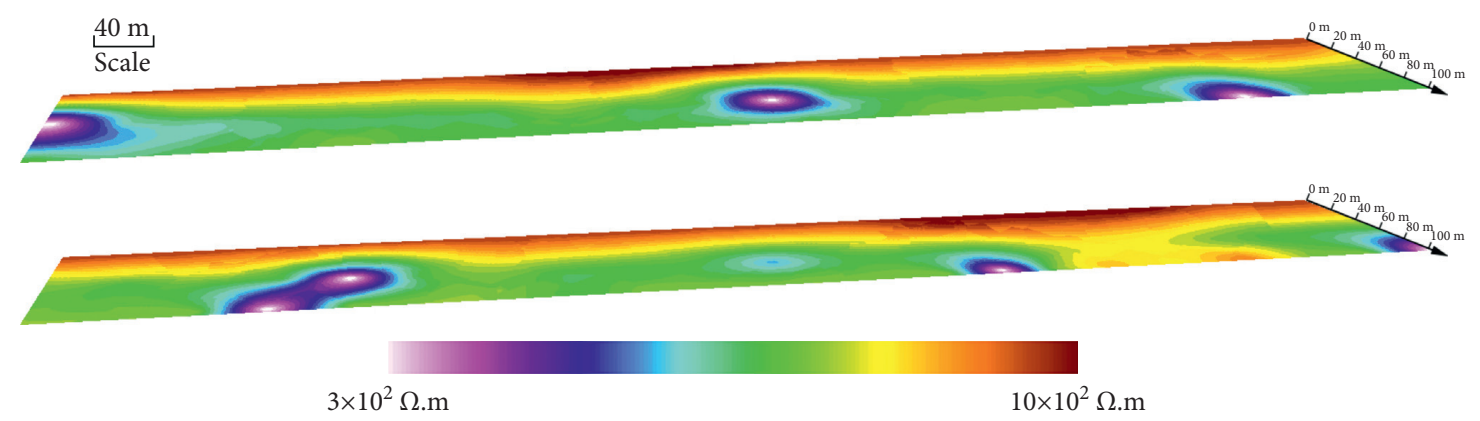

(c)

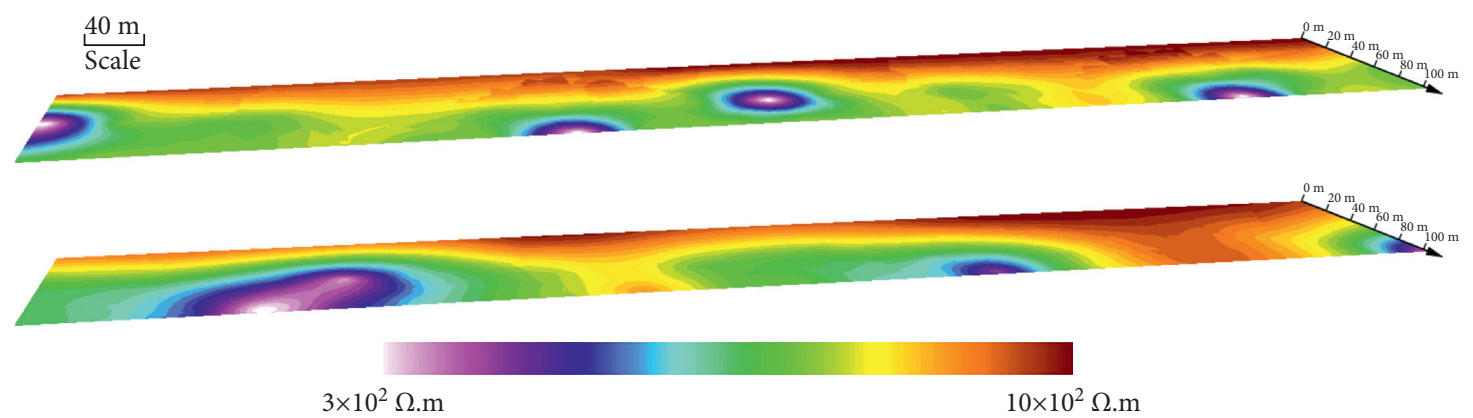

(d)

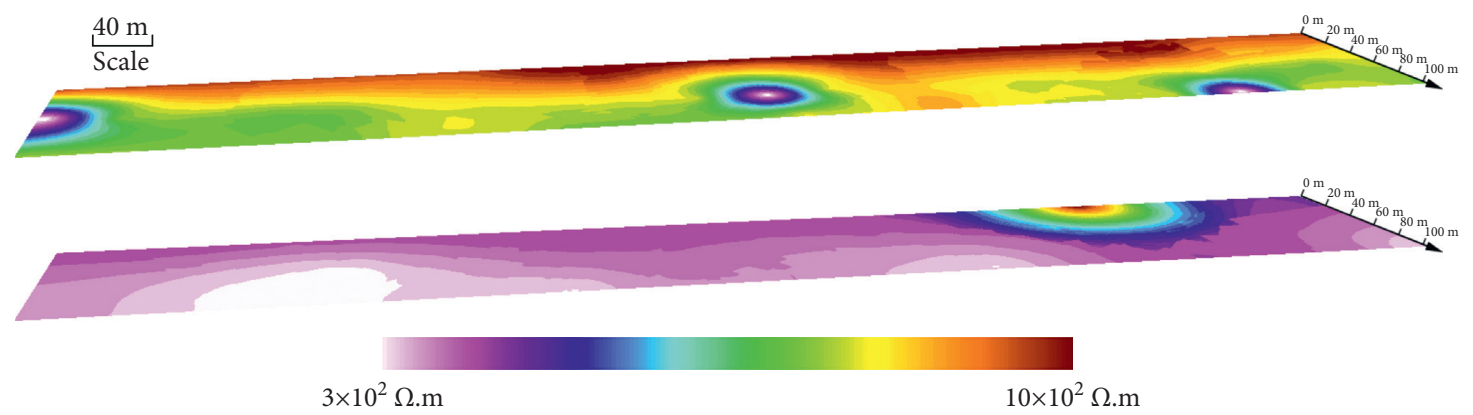

(e)

FIGURE 6: Apparent resistivity of aquifers after grouting.

rock ore body around the roadway will generate two electromagnetic fields over time. Since the two fields contain geoelectric data of the measurements made around the tunnel, determining the electrical properties of the conductive media around the roadway is done by observing the two electromagnetic fields during the interval and extracting and analyzing the observed information. A schematic of the transient electromagnetic process in the detection of electromagnetic fields is shown in Figure 4.

Figure 5 shows the spatial distribution characteristics of the apparent resistivity of the different sections of study area by using the TEM before grouting.

Most of drilled holes do not have any water in the areas with relatively normal resistivity, and most of water exit points are found in the anomaly areas with low resistivity. Figure 6 shows the spatial distribution characteristics of the apparent resistivity of different sections of study area after grouting and minimal changes of the electrical properties of the rock stratum under coal seam when the water yield of $\mathrm{L}_{11}$ is low within the range of
$40 \mathrm{~m}$, and this shows that there are no areas with low resistivity. The spatial distribution of apparent resistivity in the strata in the depth that ranges from 40 to $80 \mathrm{~m}$ shows that $\mathrm{L}_{10}$ and $\mathrm{L}_{11}$ have been transformed into aquicludes, and there is no obvious water bearing geological anomalies or concealed water cut channels within the depth range. This shows that grouting is effective and reduces the permeability of the floor so that $\mathrm{L}_{10}$ and $\mathrm{L}_{11}$ become aquicludes.

\section{Conclusions}

Grouting reinforcement has played a key role in reducing the permeability of the aquifers. In order to put into place a safe plan that mining above on aquifers, the effects of grouting reinforcement assessment are essential. This paper proposes a new method that couples GIS and the TEM to evaluate the effects of grouting reinforcement of aquifers and analyzes the spatial characteristics of the volume of the grout injected into aquifers and their water yield. 
The new method was applied in a case study in a coalmine which indicates that the method provides objective and accurate evaluation of the reinforcement with grout. The resistivity of the aquifers in this study before and after grouting and their spatial characteristics are examined, and there are six types of fissures that fill with water in accordance with the water yield. The electrical properties of the strata show that the aquifers have been transformed into aquicludes, and the effect of grouting reinforcement of aquifers is good. The new method can be used to evaluate the effects of grouting reinforcement in other underground engineering construction projects, such as tunnels and dam, in future work.

\section{Data Availability}

The datasets generated during the current study are available from the corresponding author on reasonable request.

\section{Conflicts of Interest}

The authors declare that there are no conflicts of interest in the submission of this manuscript.

\section{Authors' Contributions}

All authors approved the manuscript for publication.

\section{Acknowledgments}

The authors would like to acknowledge financial support from the National Natural Science Foundation of China under Grant no. 52174128, Scientific Research Program of Colleges, Universities in Xinjiang Uygur Autonomous Region of China under Grant no. XJEDU2016S089, and Henan College Students' Innovation and Entrepreneurship Training Program under Grant no. S202110480034.

\section{References}

[1] S. Q. Liu, Y. C. Fei, Y. Xu, L. Huang, and W. Guo, "Full-floor grouting reinforcement for working faces with large mining heights and high water pressure: a case study in China," Mine Water and the Environment, vol. 39, no. 2, pp. 268-279, 2020.

[2] Q. Wang, Q. Qin, B. Jiang, H. C. Yu, R. Pan, and S. C. Li, "Study and engineering application on the bolt-grouting reinforcement effect in underground engineering with fractured surrounding rock," Tunnelling and Underground Space Technology, vol. 84, pp. 237-247, 2019.

[3] J. Wu, P. Li, H. Qian, and J. Chen, "On the sensitivity of entropy weight to sample statistics in assessing water quality: statistical analysis based on large stochastic samples," Environmental Earth Sciences, vol. 74, no. 3, pp. 2185-2195, 2015.

[4] G. Liu, "Permo-Carboniferous paleogeography and coal accumulation and their tectonic control in the North and South China continental plates," International Journal of Coal Geology, vol. 16, no. 1-3, pp. 73-117, 1990.

[5] G. Li and W. Zhou, "Impact of karst water on coal mining in North China," Environmental Geology, vol. 49, no. 3, pp. 449-457, 2006.
[6] X. Yu, F. Pei, J. Han, W. Gao, and XW. Wang, "Ordovician limestone karst development law in Feicheng coal field," Environmental Earth Sciences, vol. 77, pp. 1-13, 2018.

[7] Q. Wu, Y. Liu, D. Liu, and W. Zhou, "Prediction of floor water inrush: the application of GIS-based AHP vulnerable index method to Donghuantuo coal mine, China," Rock Mechanics and Rock Engineering, vol. 44, no. 5, pp. 591-600, 2011.

[8] B. Guo, T. Cheng, L. Wang, T. Luo, and X. Yang, "Physical simulation of water inrush through the mine floor from a confined aquifer," Mine Water and the Environment, vol. 37, no. 3, pp. 577-585, 2017.

[9] M. Qiu, J. Han, Y. Zhou, and L. Shi, "Prediction reliability of water inrush through the coal mine floor," Mine Water and the Environment, vol. 36, no. 2, pp. 217-225, 2017.

[10] H. M. Anawar, "Impact of climate change on acid mine drainage generation and contaminant transport in water ecosystems of semi-arid and arid mining areas," Physics and Chemistry of the Earth, Parts $A / B / C$, vol. 58-60, pp. 13-21, 2013.

[11] J. Zhang, Q. Zhang, A. J. S. Spearing, X. Miao, S. Guo, and Q. Sun, "Green coal mining technique integrating miningdressing-gas draining-backfilling-mining," International Journal of Mining Science and Technology, vol. 27, no. 1, pp. 17-27, 2017.

[12] D. Xuan and J. Xu, "Grout injection into bed separation to control surface subsidence during longwall mining under villages: case study of Liudian coal mine, China," Natural Hazards, vol. 73, no. 2, pp. 883-906, 2014.

[13] D. Wang and Z. Jiang, "Characteristics of water inflow and chemical grouting treatment of a liu yuanzi coal mine shaft in the ordos basin," Mining Science and Technology, vol. 20, no. 4, pp. 607-610, 2010.

[14] ZX. Liu, SN. Dong, H. Wang, CH. Zhao, and Z. F. Zhou, "“Influences on the performance of cement-based grout used to reform the upper Middle Ordovician limestone in Hanxing mining area"," Arabian Journal of Geosciences, vol. 14, no. 13, pp. 1-15, 2021.

[15] D. Xuan, J. Li, K. Zheng, and J. Xu, “"Experimental Study of Slurry Flow in Mining-Induced Fractures during Longwall Overburden Grout Injection"," Geofluids, vol. 2020, Article ID 8877616, 10 pages, 2020.

[16] B. Yang, S. Yuan, Y. Liang, and J. Liu, "“Investigation of overburden failure characteristics due to combined mining: case study, Henan Province, China", Environmental Earth Sciences, vol. 80, p. 143, 2021.

[17] B. Yuan, Z. Li, Z. Zhao, H. Ni, Z. Su, and Z. Li, "Experimental study of displacement field of layered soils surrounding laterally loaded pile based on transparent soil," Journal of Soils and Sediments, vol. 21, no. 9, pp. 3072-3083, 2021.

[18] Y. Wu, J. Cui, J. Huang, W. Zhang, N. Yoshimoto, and L. Wen, "Correlation of critical state strength properties with particle shape and surface fractal dimension of clinker ash," International Journal of Geomechanics, vol. 21, no. 6, Article ID 04021071, 2021.

[19] B. Bai, Q. Nie, Y. Zhang, X. Wang, and W. Hu, "Cotransport of heavy metals and $\mathrm{SiO} 2$ particles at different temperatures by seepage," Journal of Hydrology, vol. 597, Article ID 125771, 2021.

[20] B. Bai, G.-c. Yang, T. Li, and G.-s. Yang, "A thermodynamic constitutive model with temperature effect based on particle rearrangement for geomaterials," Mechanics of Materials, vol. 139, Article ID 103180, 2019.

[21] A. Mortazavi and A. Maadikhah, "An investigation of the effects of important grouting and rock parameters on the 
grouting process," Geomechanics and Geoengineering, vol. 11, no. 3, pp. 219-235, 2016.

[22] J. E. Danielsen, E. Auken, F. Jørgensen, V. Søndergaard, and K. I. Sørensen, "The application of the transient electromagnetic method in hydrogeophysical surveys," Journal of Applied Geophysics, vol. 53, no. 4, pp. 181-198, 2003.

[23] R. S. Smith and A. P. Annan, "Using an induction coil sensor to indirectly measure theB-field response in the bandwidth of the transient electromagnetic method," Geophysics, vol. 65, no. 5, pp. 1489-1494, 2000 .

[24] B. Yang, W. Sui, and L. Duan, "Risk assessment of water inrush in an underground coal mine based on GIS and fuzzy set theory," Mine Water and the Environment, vol. 36, no. 4, pp. 617-627, 2017.

[25] B. Yuan, Z. H. Li, Z. L. Su, QZ. Luo, MJ. Chen, and ZQ. Zhao, "Sensitivity of multistage fill slope based on finite element model," Advances in Civil Engineering, vol. 2021, Article ID 6622936, 13 pages, 2021.

[26] B. Yuan, Z. H. Li, Y. Chen et al., "“Mechanical and microstructural properties of recycling granite residual soil reinforced with glass fiber and liquid-modified polyvinyl alcohol polymer - sciencedirect"," Chemosphere, vol. 268, Article ID 131652, 2021.

[27] B. Yang, K. Xu, and Z. Zhang, "Mitigating evaporation and desiccation cracks in soil with the sustainable material biochar," Soil Science Society of America Journal, vol. 84, no. 2, pp. 461-471, 2020.

[28] B. Yang, J. Liu, X. Zhao, and S. Zheng, "Evaporation and cracked soda soil improved by fly ash from recycled materials," Land Degradation \& Development, vol. 32, no. 9, pp. 2823-2832, 2021.

[29] B. Yang, D. Li, S. Yuan, and L. Jin, "Role of biochar from corn straw in influencing crack propagation and evaporation in sodic soils," Catena, vol. 204, Article ID 105457, 2021.

[30] H. M. Baalousha, "Groundwater vulnerability mapping of Qatar aquifers," Journal of African Earth Sciences, vol. 124, pp. 75-93, 2016.

[31] A. Yeboah-Forson, X. Comas, and D. Whitman, "Integration of electrical resistivity imaging and ground penetrating radar to investigate solution features in the Biscayne Aquifer," Journal of Hydrology, vol. 515, pp. 129-138, 2014.

[32] L. Anselin, I. Syabri, and Y. Kho, "GeoDa: an introduction to spatial data analysis," Geographical Analysis, vol. 38, no. 1, pp. 5-22, 2006.

[33] M. R. T. Dale, P. Dixon, M.-J. Fortin, P. Legendre, D. E. Myers, and M. S. Rosenberg, "Conceptual and mathematical relationships among methods for spatial analysis," Ecography, vol. 25, no. 5, pp. 558-577, 2002.

[34] Q. Meng, X. Hu, H. Pan, and Y. Xi, “Apparent resistivity for transient electromagnetic induction logging and its correction in radial layer identification," Journal of Applied Geophysics, vol. 151, pp. 328-342, 2018.

[35] B. R. Spies, "A field occurrence of sign reversals with the transient electromagnetic method*," Geophysical Prospecting, vol. 28, no. 4, pp. 620-632, 1980.

[36] A. Ziolkowski, R. Parr, D. Wright et al., “"Multi-transient electromagnetic repeatability experiment over the North Se. Harding field"," Geophysical Prospecting, vol. 58, no. 6, pp. 1159-1176, 2010. 